\title{
Characteristics of spores formed by surface and submerged cultures of Streptomyces albidoflavus SMF301
}

\author{
KYE JOON LEE* and Yong TAIK Rho \\ Department of Microbiology and Research Centre for Molecular Microbiology, Seoul National University, \\ Seoul 151-742, Korea
}

(Received 30 March 1993; revised 8 June 1993; accepted 2 August 1993)

\begin{abstract}
Streptomyces albidoflavus SMF301 produced abundant spores in submerged cultures (submerged spores) as well as on solid media (aerial spores). The content of carbon, hydrogen, nitrogen, and phosphorus in submerged and aerial spores was similar; however, the contents of metal ions $\left(\mathrm{K}^{+}, \mathrm{Na}^{+}, \mathrm{Ca}^{2+}\right.$ and $\left.\mathrm{Mg}^{2+}\right)$ were very different. Glutamic acid, alanine, and glycine, all known to be cell-wall components, were the major amino acids in both types of spores. However, cysteine was more abundant in submerged spores than in aerial spores. The major fatty acid in aerial spores was $n-C_{18}(61 \cdot 74 \%)$, whereas in submerged spores it was ai- $C_{16}(33.68 \%)$. The contents of ai- $C_{14}$, and ai- $\mathrm{C}_{17}$ in submerged spores were also very much higher than in aerial spores. Unsaturated fatty acids were found in both kinds of spores but not in mycelium; they were particularly abundant in submerged spores. The composition of menaquinones in the two kinds of spores also varied. The resistance of aerial spores to lysozyme digestion, mild acid treatment, heating and desiccation was higher than that of submerged spores, but the submerged spores were more resistant to sonication.
\end{abstract}

\section{Introduction}

Streptomyces spp. are important as producers of useful metabolites. They are also of interest because of their unique morphological complexity: they form a substrate mycelium, as well as an aerial mycelium that differentiates into arthrospores. Aerial growth and spore formation probably reflect nutrient limitation, reduced growth rate and the accumulation of growth inhibitors or extracellular pheromones. Studies on the mechanisms involved in cell differentiation have been carried out mostly on solid cultures (Chater, 1984, 1989, 1991; Chater et al., 1988). However, spore formation in submerged cultures would give some advantages in the elucidation of relationships between environmental change and spore formation, and in quantitative analysis of the processes. Some species of Streptomyces can sporulate in submerged culture, and this has led to some physiological analyses (Kendrick \& Ensign, 1983; Ensign, 1988; Koepsel \& Ensign, 1984; Huber et al., 1987; Ochi, 1987; Daza et al., 1989; Glazebrook et al., 1990).

We found, in soil, a strain of Streptomyces (SMF301) that produced abundant spores both in submerged

${ }^{*}$ Author for correspondence. Tel. $+8228856705 ;$ fax +822882 9285. cultures and on solid cultures (Shin \& Lee, 1986; Jeong et al., 1988; Rho et al., 1988, 1989). This strain was classified as Streptomyces albidoflavus by numerical analysis of taxonomic characters (Williams et al., $1983 a, b)$ using TAXON, an identification probability matrix (Rho et al., 1992). We report here the cellular composition of the spores and their resistance to extreme conditions.

\section{Methods}

Micro-organism and media. The micro-organism used was Streptomyces albidoflavus SMF301. Rich medium consisted of (w/v): $1 \%$ glucose, $0.2 \%$ peptone, $0.1 \%$ yeast extract, $0.1 \%$ beef extract, and $1.8 \%$ agar for solid cultures. Chemically defined medium contained (w/v): $2 \%$ glucose, $0.1 \% \mathrm{NH}_{4} \mathrm{Cl}$ or $0.5 \%$ Na-caseinate, $0.13 \%$ $\mathrm{KH}_{2} \mathrm{PO}_{4}, \quad 0.09 \% \mathrm{Na}_{2} \mathrm{HPO}_{4}, 0.06 \% \mathrm{MgSO}_{4} .7 \mathrm{H}_{2} \mathrm{O}, 0.0001 \%$ trace elements $\left(\mathrm{FeSO}_{4} \cdot 7 \mathrm{H}_{2} \mathrm{O}, \mathrm{MnCl}_{2} \cdot 4 \mathrm{H}_{2} \mathrm{O}, \mathrm{CaCl}_{2} \cdot 2 \mathrm{H}_{2} \mathrm{O}\right.$, and $\mathrm{ZnSO}_{4}$. $7 \mathrm{H}_{2} \mathrm{O}$ ). The initial $\mathrm{pH}$ of the media was adjusted to $7 \cdot 0$ before steam sterilization; the phosphate and magnesium salts were sterilized separately and added aseptically.

Strain maintenance and culture conditions. Strains were maintained by transferring to slopes of rich agar medium each month and storing at $4{ }^{\circ} \mathrm{C}$. The spores developed on rich agar medium were suspended in rich liquid medium supplemented with glycerol $(10 \%, \mathrm{v} / \mathrm{v})$ and stored at $-70^{\circ} \mathrm{C}$ (Wellington \& Williams, 1978). The frozen spore suspensions (about $10^{9}$ spores $\mathrm{ml}^{-1}$ ) were thawed at ambient temperature for use as inocula. 
Surface culture was carried out in Petri plates on rich or chemically defined medium at $28^{\circ} \mathrm{C}$. Submerged cultures in $50 \mathrm{ml}$ chemically defined medium in $100 \mathrm{ml}$ baffled flasks were inoculated with $1 \mathrm{ml}$ of spore suspension and incubated for $5 \mathrm{~d}$ at $28^{\circ} \mathrm{C}$ on a rotary shaker (150 r.p.m.). In flask cultures, the $\mathrm{pH}$ was maintained at 7.1 by addition of $48 \mathrm{~mm}$-MOPS buffer. The seed culture was used to inoculate 2 litres of chemically defined medium in a jar fermentor (3 litre; Korea Fermentor $\mathrm{Co}$.). The culture temperature was maintained at $28{ }^{\circ} \mathrm{C}$, and the $\mathrm{pH}$ was controlled at 7.0 by automatic addition of $1 \mathrm{M}-\mathrm{HCl}$ or $1 \mathrm{M}-$ $\mathrm{NaOH}$. Aeration and agitation were controlled at $1.0 \mathrm{v} / \mathrm{v} \mathrm{min}^{-1}$ and 200 r.p.m., respectively.

Analysis of growth and spore formation. Mycelium and spores in submerged cultures were harvested by centrifugation at $15000 \mathrm{~g}$ for $10 \mathrm{~min}$, and then washed twice with physiological saline solution and once with distilled water. The washed cells were dried at $100^{\circ} \mathrm{C}$ for $12 \mathrm{~h}$. Growth is expressed as dry cell weight. The procedure for distinguishing spores from mycelium was based on results obtained during the present studies; the number of spores formed in submerged cultures (spore forming units) was counted as follows: culture broth $(5 \mathrm{ml})$ was sonicated for $5 \mathrm{~min}$ at $100 \mathrm{~W}$ using a sonic dismembrator (Model 300, Fisher). The sonicated cell suspension $(0.5 \mathrm{ml})$ was mixed gently with $0.1 \mathrm{M}-\mathrm{HCl}(4.5 \mathrm{ml})$; after $5 \mathrm{~min}$, it was diluted adequately in physiological saline solution and spread on rich agar medium. Colonies were counted after $4 \mathrm{~d}$ at $28^{\circ} \mathrm{C}$.

Characterization of spores from surface and submerged cultures. Morphological characteristics were observed with a phase-contrast microscope (Nikon Labophot) and a scanning electron microscope (Stereoscan 260 SEM). Vegetative mycelium growing rapidly in submerged culture was harvested by centrifugation at $3000 \mathrm{~g}$ for $5 \mathrm{~min}$. Aerial spores and submerged spores were separated from mycelium by passing suspensions through glass wool (Hopwood et al., 1985).

The $\mathrm{C}, \mathrm{H}$, and $\mathrm{N}$ contents of spores and mycelia were analysed with an elemental analyser (model $2400 \mathrm{CHN}$, Perkin-Elmer) and the $\mathrm{P}$ content was estimated spectrophotometrically after reaction with ammonium molybdate and 1-amino-2-naphthol-4-sulphonic acid by the method of Herbert et al. (1971). Trace elements were measured with an atomic absorption analyser (Model AA-880 Mark II, Jarrel-Ash). Total carbohydrate was determined by reaction with phenol in sulphuric acid (Herbert et al., 1971). Trehalose was measured by HPLC using a differential refractometer for detection as reported by McBride \& Ensign (1987a). Crude protein content was calculated by assuming that crude protein $=$ total $\mathrm{N} \times 6.25$. In the same samples, the Biuret method (Gornall et al., 1949) was used to measure protein content; the latter measurement gave the protein content without interference from nucleic acids and most other cellular macromolecules containing nitrogen (Herbert et al., 1971). The amino acid profiles were determined with an amino acid analyser (Model 510, Waters) as described by Bidlingmeyer et al. (1984) and Gaitonde (1967). Fatty acids were analysed by gas chromatography [Model MSD (5791A), Hewlett Packard] as described by Minnikin et al. (1978).

The resistance of vegetative mycelia, aerial spores, and submerged spores to various treatments was measured by known procedures as follows: sonication (Koepsel \& Ensign, 1984): lysozyme (Glazebrook et al., 1990): mild acid (McBride \& Ensign, 1987a, b); heat (Daza et al., 1989). In the desiccation treatment, spore suspensions (about $10^{9}$ spores) were passed through a membrane filter disc $(0.2 \mu \mathrm{m}$, Millipore) and the spore filter cakes were dried for 2 weeks over $\mathrm{P}_{2} \mathrm{O}_{5}$; the moisture content in the desiccator was maintained at less than $0.01 \%$ humidity, measured by a moisture meter (Karl Fisher).

Chemicals, reagents, and reproducibility. Lysozyme, NTG, amino acids and fatty acids were from commercial suppliers. Each experiment was repeated three times; mean values are given.

\section{Results \\ Growth characteristics and spore formation in submerged culture}

Mycelium and spores of $S$. albidoflavus SMF301 grown on chemically defined agar medium were observed with a scanning electron microscope (Fig. 1). The spore surface was smooth and lacked ornamentation. Morphological changes (Fig. 2) and spores formed in a submerged culture (Fig. 3) were also examined. The inoculum spores germinated and then formed a vegetative mycelium. The vegetative mycelium was extensively branched but not fragmented, and verticils were not observed. However, from the middle of the exponential growth phase the vegetative mycelium developed chains of spores.

Sporulation in a submerged culture of SMF 301 began in the middle of the growth phase; at that time the amounts of residual glucose and ammonium ions were relatively high (Fig. 4). Thus, carbon or nitrogen limitation did not seem to be responsible. The spore chains were segmented to give free submerged spores in the stationary phase of the culture. The submerged spores were slightly larger than aerial spores, but were otherwise similar.

\section{Cellular components of the spores and mycelia}

The contents of $\mathrm{C}, \mathrm{H}, \mathrm{N}, \mathrm{P}, \mathrm{K}, \mathrm{Na}, \mathrm{Ca}$, and $\mathrm{Mg}$ in mycelia and spores are shown in Table 1 . The contents of $\mathrm{C}$, and $\mathrm{H}$ were comparable, but the content of $\mathrm{N}$ in the mycelium was higher than in spores, indicating a higher content of protein. Moreover, spores contained more $\mathrm{P}$, $\mathrm{Ca}$, and $\mathrm{Mg}$. Conversely, the content of $\mathrm{K}$ and $\mathrm{Na}$ in the

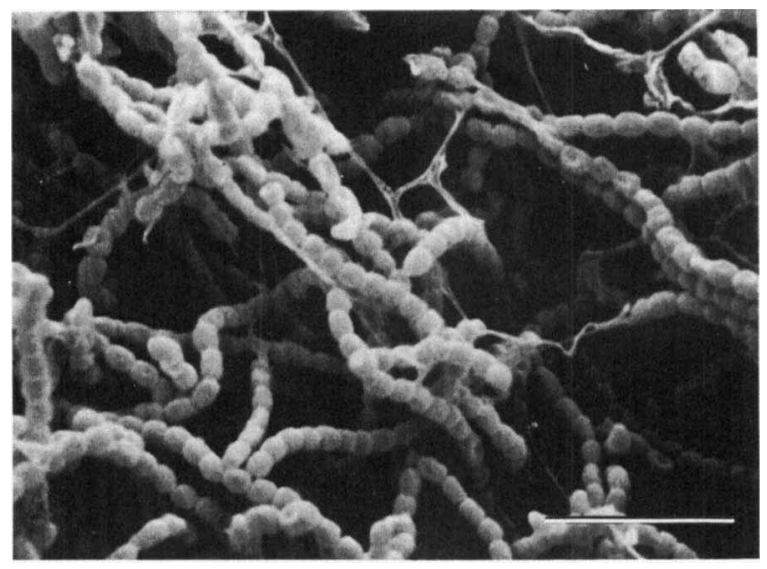

Fig. 1. Scanning electron photomicrograph of S. albidoflavus SMF301 grown on rich agar medium for $7 \mathrm{~d}$ at $28^{\circ} \mathrm{C}$. Bar, $5 \mu \mathrm{m}$. 


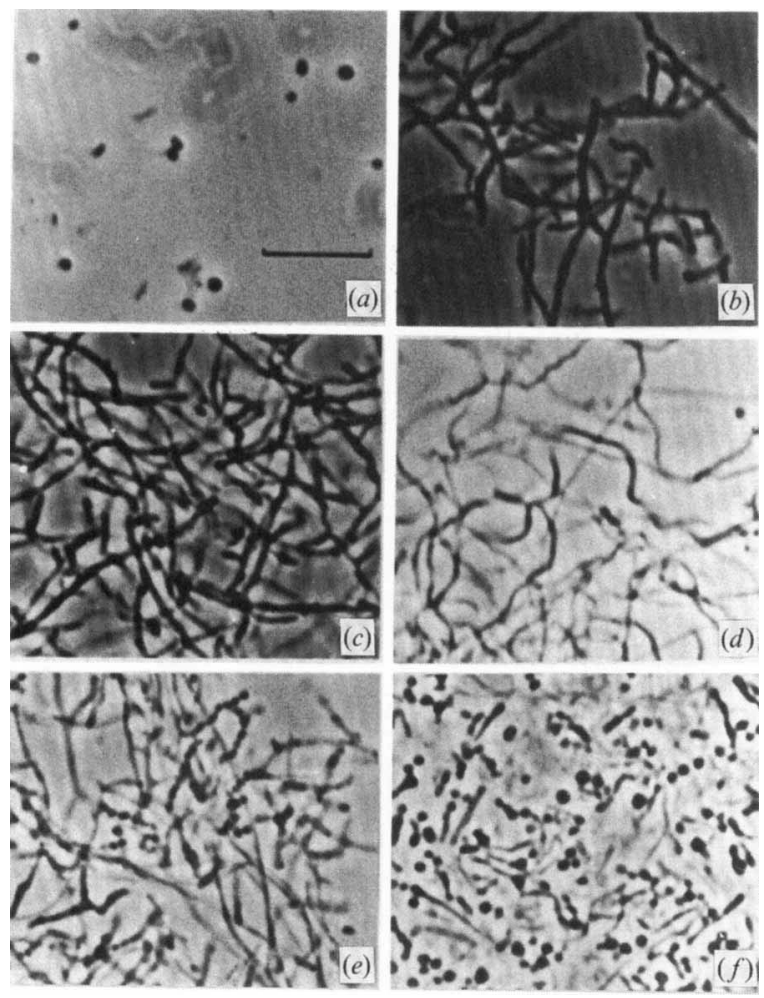

Fig. 2. Phase contrast photomicrographs of $S$. albidoflavus SMF301 from a submerged culture in chemically defined medium. Cells were harvested from the culture at $(a), 0 \mathrm{~h} ;(b), 24 \mathrm{~h} ;(c), 48 \mathrm{~h} ;(d), 60 \mathrm{~h} ;(e)$, $72 \mathrm{~h} ;(f), 96 \mathrm{~h}$. Bar, $10 \mu \mathrm{m}$.

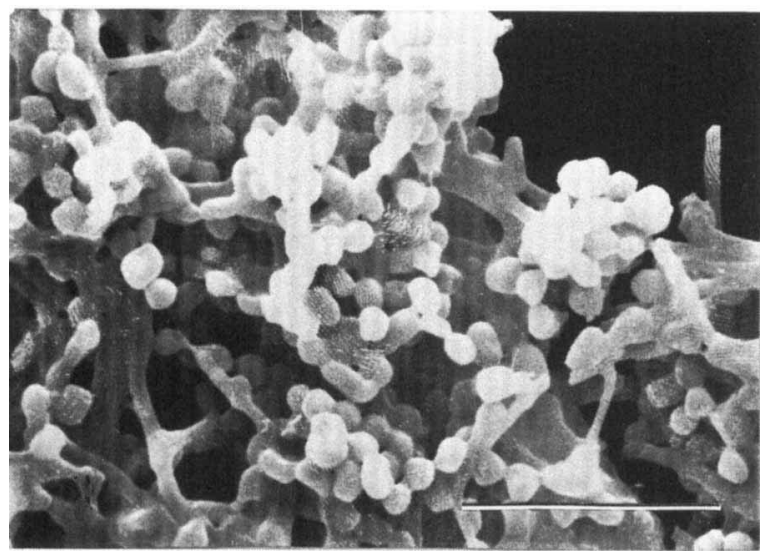

Fig. 3. Scanning electron photomicrograph of spores of S. albidoflavus SMF301. The spores and mycelia were collected from a submerged culture in chemically defined medium at $7 \mathrm{~d}$. Mycelia and spores were coated with gold in an argon gas chamber. Bar, $5 \mu \mathrm{m}$.

mycelium was much higher than in aerial and submerged spores.

The contents of total carbohydrate, trehalose, and

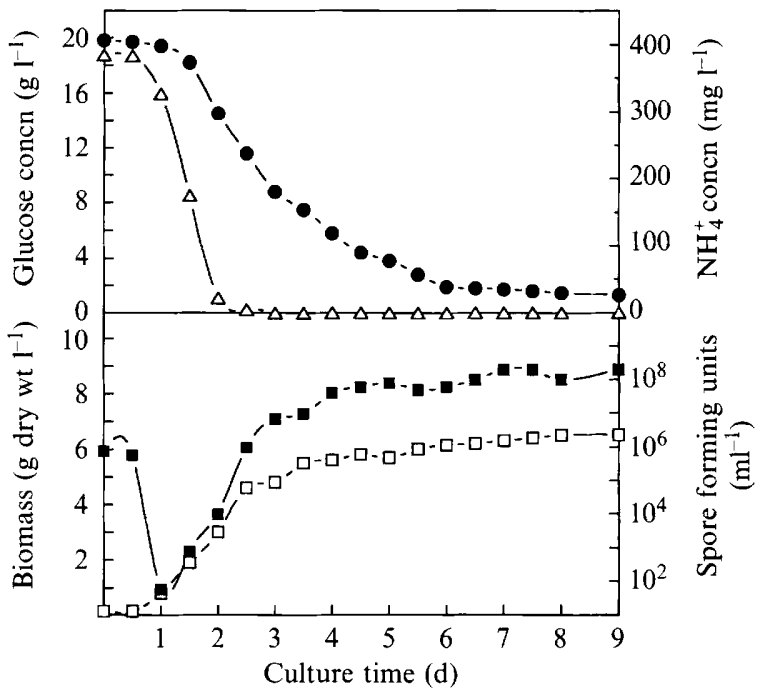

Fig. 4. Changes in concentration of glucose $(\bullet), \mathrm{NH}_{4}^{+}(\triangle)$, biomass ( $\square$ ), and spore forming units $(\boldsymbol{\square})$ in a submerged culture of $S$. albidoflavus SMF301. Cultures were grown at $28^{\circ} \mathrm{C}$ in chemically defined medium containing Na-caseinate as the sole nitrogen source.

Table 1. Contents of $\mathrm{C}, \mathrm{H}, \mathrm{N}, \mathrm{P}, \mathrm{K}, \mathrm{Na}, \mathrm{Ca}$ and $\mathrm{Mg}$ in mycelium, aerial spores and submerged spores of S. albidoflavus SMF301

Cultures were grown at $30^{\circ} \mathrm{C}$ for $5 \mathrm{~d}$ in rich liquid medium for submerged spores and vegetative mycelium, and on rich agar medium for aerial spores

\begin{tabular}{|c|c|c|c|}
\hline & \multicolumn{3}{|c|}{ Percentage content in: } \\
\hline & Mycelium & $\begin{array}{l}\text { Aerial } \\
\text { spores }\end{array}$ & $\begin{array}{c}\text { Submerged } \\
\text { spores }\end{array}$ \\
\hline $\mathrm{C}$ & $43 \cdot 18$ & $43 \cdot 43$ & $43 \cdot 01$ \\
\hline $\mathrm{H}$ & $6 \cdot 75$ & $6 \cdot 83$ & $6 \cdot 91$ \\
\hline $\mathrm{N}$ & $10 \cdot 24$ & $8 \cdot 10$ & 8.49 \\
\hline $\mathrm{P}$ & 1.25 & $2 \cdot 47$ & 2.71 \\
\hline $\mathrm{K}$ & $2 \cdot 13$ & $1 \cdot 39$ & 0.69 \\
\hline $\mathrm{Na}$ & $1 \cdot 31$ & 1.41 & $0 \cdot 87$ \\
\hline $\mathrm{Ca}$ & 0.04 & 0.06 & 0.07 \\
\hline $\mathrm{Mg}$ & $0 \cdot 11$ & $0 \cdot 13$ & $0 \cdot 14$ \\
\hline
\end{tabular}

protein in mycelia and spores are shown in Table 2. Aerial spores contained more carbohydrate than submerged spores, and their content of trehalose was higher; trehalose was not detected in the vegetative mycelium. The ratio of Biuret protein to crude protein was higher in the mycelium than in submerged and aerial spores, indicating that the spore forms contained more nonprotein nitrogen compounds such as nucleic acids and cell water mucopeptides. The molar percentage amino acid compositions in vegetative mycelia, aerial spores and submerged spores are shown in Table 3. Except for the cysteine content, the amino acid compositions of the 
Table 2. Total carbohydrate, trehalose, crude protein and purified protein in mycelium, aerial spores and submerged spores of S. albidoflavus SMF301

Culture conditions were the same as described in Table 1.

\begin{tabular}{|c|c|c|c|}
\hline & \multicolumn{3}{|c|}{ Percentage content in: } \\
\hline & Mycelium & $\begin{array}{l}\text { Aerial } \\
\text { spores }\end{array}$ & $\begin{array}{l}\text { Submerged } \\
\text { spores }\end{array}$ \\
\hline Total carbohydrate* & $16 \cdot 02$ & $17 \cdot 49$ & $13 \cdot 82$ \\
\hline Trehalose* & ND & $8 \cdot 70$ & 6.90 \\
\hline Crude protein*† & $64 \cdot 00$ & $50 \cdot 63$ & 53.06 \\
\hline Pure protein* & $61 \cdot 30$ & $44 \cdot 50$ & $33 \cdot 70$ \\
\hline
\end{tabular}

ND, Not detected.

* Lyophilized samples were used for assay.

$\dagger$ Based on a protein nitrogen index of 6.25 .

$\ddagger$ Analysed by the Biuret method.

Table 3. Molar percentage composition of amino acids in mycelium aerial spores and submerged spores of S. albidoflavus SMF301

Culture conditions were the same as described in Table 1 .

\begin{tabular}{|c|c|c|c|}
\hline \multirow[b]{2}{*}{ Amino acid } & \multicolumn{3}{|c|}{ Percentage content in: } \\
\hline & Mycelium & $\begin{array}{l}\text { Aerial } \\
\text { spores }\end{array}$ & $\begin{array}{l}\text { Submerged } \\
\text { spores }\end{array}$ \\
\hline Aspartic acid & 7.56 & 6.68 & $4 \cdot 76$ \\
\hline Asparagine & $0 \cdot 80$ & 0.69 & $0 \cdot 50$ \\
\hline Glutamic acid & 16.55 & $18 \cdot 97$ & $18 \cdot 25$ \\
\hline Glutamine & $1 \cdot 79$ & $2 \cdot 10$ & 1.98 \\
\hline Serine & $5 \cdot 78$ & 6.09 & $6 \cdot 25$ \\
\hline Glycine & 11.27 & $14 \cdot 08$ & 14.09 \\
\hline Histidine & 1.79 & $1 \cdot 50$ & $1 \cdot 28$ \\
\hline Arginine & 5.57 & 4.09 & 4.06 \\
\hline Threonine & $5 \cdot 39$ & $4 \cdot 70$ & $3 \cdot 94$ \\
\hline Alanine & 14.94 & 16.07 & $19 \cdot 57$ \\
\hline Proline & $5 \cdot 57$ & $4 \cdot 18$ & $4 \cdot 17$ \\
\hline Tyrosine & $0 \cdot 70$ & $0 \cdot 40$ & 0.39 \\
\hline Valine & $6 \cdot 48$ & $6 \cdot 57$ & 6.54 \\
\hline Methionine & $0 \cdot 80$ & $0 \cdot 50$ & 0.59 \\
\hline Isoleucine & 3.08 & 2.89 & $2 \cdot 78$ \\
\hline Leucine & $5 \cdot 67$ & 4.99 & 4.56 \\
\hline Phenylalanine & $2 \cdot 49$ & $2 \cdot 39$ & $2 \cdot 78$ \\
\hline Lysine & 3.29 & 2.79 & $2 \cdot 48$ \\
\hline Cysteine & 0.25 & $0 \cdot 15$ & 0.80 \\
\hline Tryptophan & $0 \cdot 23$ & $0 \cdot 17$ & $0 \cdot 23$ \\
\hline Total & $100 \cdot 00$ & $100 \cdot 00$ & $100 \cdot 00$ \\
\hline
\end{tabular}

spore samples were nearly identical. Glutamic acid, alanine, and glycine were the major amino acids in all morphological forms.

The major fatty acid in aerial spores was $\mathrm{n}-\mathrm{C}_{18}$ $(61.74 \%)$ and that in submerged spores was ai- $\mathrm{C}_{16}$ $(33.66 \%)$ (Table 4). The content of unsaturated fatty acids, such as $n-C_{15: 1}, n-C_{16: 1}, i-C_{17: 1}, n-C_{17: 1}$ and $n-C_{18: 2}$ in submerged spores was much higher than in aerial
Table 4. Fatty acid composition (\%) in mycelium, aerial spores and submerged spores of $S$. albidoflavus SMF301

Culture conditions were the same as described in Table 1.

\begin{tabular}{|c|c|c|c|}
\hline \multirow[b]{2}{*}{ Fatty acid } & \multicolumn{3}{|c|}{ Percentage content in: } \\
\hline & Mycelium & $\begin{array}{l}\text { Aerial } \\
\text { spores }\end{array}$ & $\begin{array}{c}\text { Submerged } \\
\text { spores }\end{array}$ \\
\hline $\mathrm{i}-\mathrm{C}_{14}$ & 2.85 & 0.39 & 0 \\
\hline ai- $C_{14}^{14}$ & 0 & 0 & $2 \cdot 33$ \\
\hline$n-C_{14}$ & 0 & 0.58 & $2 \cdot 40$ \\
\hline $\mathrm{i}-\mathrm{C}_{15}$ & $12 \cdot 52$ & 1.01 & $3 \cdot 61$ \\
\hline ai- $\mathrm{C}_{15}$ & $28 \cdot 82$ & 1.74 & $9 \cdot 34$ \\
\hline$n-C_{15}$ & 0.19 & 1.43 & 1.43 \\
\hline Unsaturated $n-C_{15 \cdot 1}$ & 0 & $0 \cdot 24$ & 1.39 \\
\hline $\mathrm{i}-\mathrm{C}_{16}$ & $11 \cdot 34$ & 0 & 0 \\
\hline $\mathrm{ai}-\mathrm{C}_{16}$ & 0 & $1 \cdot 84$ & 33.69 \\
\hline Unsaturated $n-C_{16.1}$ & 0 & 0 & $2 \cdot 30$ \\
\hline $\mathrm{n}-\mathrm{C}_{16}$ & $16 \cdot 10$ & 5.86 & 0 \\
\hline Unsaturated $\mathrm{i}-\mathrm{C}_{17 \cdot 1}$ & 0 & 0 & $1 \cdot 39$ \\
\hline Unsaturated $n-C_{17: 1}$ & 0 & $0 \cdot 11$ & 1.54 \\
\hline $\mathrm{i}-\mathrm{C}_{17}$ & 11.78 & 0.39 & 0 \\
\hline ai- $C_{17}$ & $16 \cdot 59$ & $1 \cdot 15$ & $5 \cdot 37$ \\
\hline $\mathrm{n}-\mathrm{C}_{17}$ & 0 & 0.27 & 0 \\
\hline Cyclopropane- $\mathrm{C}_{15}$ & 0 & 0.88 & 0 \\
\hline Unsaturated $n-C_{18: 2}$ & 0 & 0 & $13 \cdot 84$ \\
\hline 2-Hexyl cyclopropane- $\mathrm{C}_{18}$ & 0 & 0 & 4.78 \\
\hline $\mathrm{n}-\mathrm{C}_{18}$ & 0 & 61.74 & $9 \cdot 21$ \\
\hline $\mathrm{n}-\mathrm{C}_{19}$ & 0 & 7.09 & 0 \\
\hline $\mathrm{ai}-\mathrm{C}_{20}$ & 0 & $0 \cdot 18$ & 0 \\
\hline$n-C_{20}$ & 0 & 0.87 & $7 \cdot 39$ \\
\hline $\mathrm{ai}-\mathrm{C}_{22}$ & 0 & $15 \cdot 44$ & 0 \\
\hline Total & 100 & 100 & 100 \\
\hline
\end{tabular}

spores but the unsaturated fatty acids were not present in the vegetative mycelium. Furthermore, the content of anteiso-branched fatty acids in submerged spores was particularly different from that in aerial spores.

The composition of menaquinones in the mycelium showed the typical pattern of the genus Streptomyces, with only MK- $9\left(\mathrm{H}_{6}\right)$ and MK- $9\left(\mathrm{H}_{8}\right)$ present. However, the major and minor menaquinones in the aerial spores were MK- $9\left(\mathrm{H}_{4}\right)$ and MK-9( $\left.\mathrm{H}_{6}\right)$, respectively, and in the submerged spores were MK-9 $\left(\mathrm{H}_{6}\right)$ and $\mathrm{MK}-9\left(\mathrm{H}_{4}\right)$, respectively.

\section{Survival characteristics of spores and mycelia}

Aerial and submerged spores were more resistant to mild acid, lysozyme, desiccation and heat than the vegetative mycelia (Fig. $5 a-d$ ). However, significant differences between submerged spores and aerial spores appeared in lysozyme sensitivity, aerial spores being more resistant to lysozyme than submerged spores (Fig. $5 b$ ). However, submerged spores were more resistant to sonication than aerial spores (Fig. $5 e$ ). Since the submerged spores were clearly distinguished from vegetative mycelia by soni- 

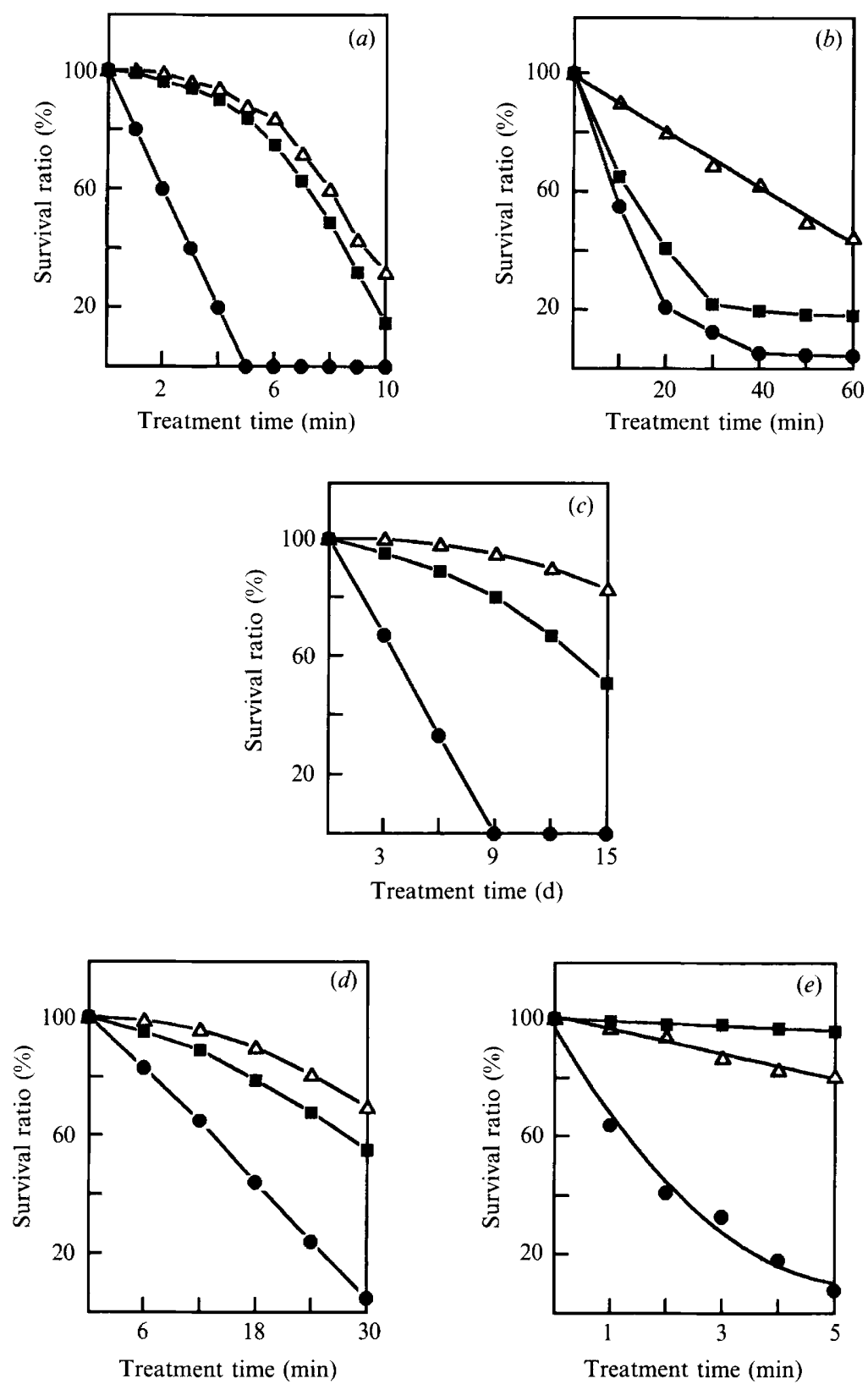

cation, we selected sonication treatment to differentiate quantitatively between submerged spores and the vegetative mycelium of $S$. albidoflavus SMF301.

\section{Discussion}

The content of $\mathrm{Ca}$ and $\mathrm{Mg}$ were higher in submerged spores. This finding is in agreement with a report that the content of Ca in spores of Streptomyces spp. was high, and that $\mathrm{Ca}^{2+}$ ions were incorporated into spores during spore formation and released at spore germination (Salas et al., 1983). The content of trehalose in aerial spores was higher than in the submerged spores. It has been reported that trehalose is the major carbohydrate in Streptomyces spores (Ensign, 1978; Brana et al., 1986), and also that the resistance of actinomycete spores to heat and desiccation is linked closely to their content of trehalose (Kendrick \& Ensign, 1983; Dworkin, 1985; McBride \& Ensign, 1987a,b).

The profiles of amino acids in spores were very similar; glutamic acid, alanine and glycine were the major amino acids. LL-diamino pimelic acid, alanine, glutamic acid, and glycine were found in the hydrolysate of cell walls of S. albidoflavus SMF301 (Rho et al., 1992). The higher contents of glutamic acid, alanine, and glycine in spores 
compared to those in vegetative mycelia suggest that the spore cell wall was thicker than that of the vegetative mycelium. The cysteine contents of submerged spores and aerial spores were different, which might contribute to the different resistances to various treatments (Fig. 5a-e).

The profiles of fatty acids in aerial and submerged spores were very different. The unsaturated fatty acid content of submerged spores was remarkably high; it is noteworthy that unsaturated fatty acids have not been detected previously in Streptomyces (Locci, 1989). Furthermore, the ai- $\mathrm{C}_{14}$, ai- $\mathrm{C}_{15}$, ai- $\mathrm{C}_{16}$, ai- $\mathrm{C}_{17}$ contents were also very much higher in submerged spores, although ai$\mathrm{C}_{20}$ and ai- $\mathrm{C}_{22}$ were not detected.

Although MK-9 $\left(\mathrm{H}_{6}\right)$ and MK-9 $\left(\mathrm{H}_{8}\right)$ represent the typical pattern of menaquinones in the genus of Streptomyces (Lechevalier \& Lechevalier, 1980), we found that the major and minor menaquinones in aerial spores were MK- $9\left(\mathrm{H}_{4}\right)$ and MK- $9\left(\mathrm{H}_{6}\right)$, respectively, while in submerged spores, they were MK- $9\left(\mathrm{H}_{6}\right)$ and $\mathrm{MK}$ $9\left(\mathrm{H}_{4}\right)$, respectively. Thus the menaquinone profiles change during cell morphogenesis in $S$. albidoflavus SMF301.

The higher survival of spores subjected to harsh treatments might be due to their thicker cell wall. The higher contents of $\mathrm{P}, \mathrm{Ca}$, and $\mathrm{Mg}$ in aerial and submerged spores compared to vegetative mycelia might also contribute to their resistance to such treatments. The resistance of submerged spores to mild acid, desiccation and heat was similar to that of aerial spores, but the higher resistance of the submerged spores to sonication might result from the higher contents of unsaturated fatty acids and anteiso-branched fatty acids, which are thought to greatly increase membrane fluidity (Tung et al., 1991).

We thank Professors K. F. Chater (John Innes, Norwich, UK) and M. Goodfellow (Newcastle upon Tyne, UK) for discussions throughout the studies, Dr D. Bourne (New South Wales, Australia) for fatty acid analysis and $\mathrm{Mr}$ J. A. Foley (Lancaster, UK) for editing the English. This work was supported by a research grant from the Research Centre for Molecular Microbiology (RCMM) sponsored by the Korea Science and Engineering Foundation (KOSEF).

\section{References}

BidlingmeYer, B. A., Cohen, S. A. \& Tarvin, T. L. (1984). Rapid analysis of amino acids using pre-column derivatization. Journal of Chromatography 336, 93-104.

Brana, A. F., Mendez, C., Diaz, L. A., Manzanal, M. B. \& Hardisson, C. (1986). Glycogen and trehalose accumulation during colony development in Streptomyces antibioticus. Journal of General Microbiology 132, 1319-1326.

CHATER, K. F. (1984). Morphological and physiological differentiation in Streptomyces. In Microbial Development, pp. 89-115. Edited by R. Losick \& L. Shapiro. Cold Spring Harbor, NY: Cold Spring Harbor Laboratory.

Chater, K. F. (1989). Sporulation in Streptomyces. In Regulation of
Procaryotic Development, pp. 277-299. Edited by I. Smith, R. A. Slepecky \& P. Setlow. Washington, DC: American Society for Microbiology.

Chater, K. F. (1991). Saps, hydrophobins and aerial growth. Current Biology 1, 318-320.

Chater, K. F., Lawlor, E. J., Mendez, C., Bruton, C. J., Davis, N. K., Plaskitt, K., Guthrie, E. P., Daly, B. L., Baylis, H. A. \& Trong, K. V. (1988). Gene expression during Streptomyces development. In Biology of Actinomycetes '88. Proceedings of 7th ISBA, pp. 64-70. Edited by Y. Okami. Tokyo: Japan Scientific Societies Press.

Daza, A., Martin, J. F., Dominguez, A. \& Gil, J. A. (1989). Sporulation of several species of Streptomyces in submerged culture after nutritional downshift. Journal of General Microbiology 135, 2483-2491.

Dworkin, M. (1985). Streptomyces. In Developmental Biology of the Bacteria, pp. 85-104. Edited by D. Martin. Menlo Park, CA: The Benjamin/Cummings Publishing Co. Inc.

Ensign, J. C. (1978). Formation properties and germination of Actinomycetes spores. Annual Review of Microbiology 32, 185-219.

ENSIGN, J. C. (1988). Physiological regulation of sporulation of Streptomyces griseus. In Biology of Actinomycetes '88. International Symposium on the Biology of Actinomycetes, pp. 309-315. Edited by Y. Okami. Tokyo: Japan Scientific Society Press.

GaitonDE, M. K. (1967). A spectrophotometric method for the direct determination of cysteine in the presence of other naturally occurring amino acids. Biochemical Journal 104, 627-633.

Glazebrook, M. A., Doull, J. L., Stuttard, C. \& Vining, L. C. (1990). Sporulation of Streptomyces venezuelae in submerged cultures. Journal of General Microbiology 136, 581-588.

Gornall, A. G., Bardawill, C. J. \& David, M. M. (1949). The determination of serum proteins by means of the Biuret reaction. Journal of Biological Chemistry 177, 751-766.

Her bert, D., Phipps, P. J. \& Strange, R. E. (1971). Chemical analysis of microbial cells. Methods in Microbiology 5B, 265-278.

Hopwood, D. A., Bibb, M. J., Chater, K. F., Kieser, T., Bruton, C. J., Kieser, H. M., Lydiate, D. J., Smith, C. P., Ward, J. M. \& SCHREMPF, H. (1985). Genetic Manipulation of Streptomyces, A Laboratory Manual. Norwich, UK: The John Innes Foundation.

Huber, F. M., Pieper, R. L. \& Mertz, F. P. (1987). Sporulation of Streptomyces roseosporus in submerged culture. Journal of Industrial Microbiology 2, 235-241.

Jeong, B. C., Shin, H. S. \& LeE, K. J. (1988). Relationship between sporulation and synthesis of alkaline protease in Streptomyces $\mathrm{sp}$. Korean Journal of Microbiology 26, 355-361.

KENDRICK, K. E. \& ENSIGN, J. C. (1983). Sporulation of Streptomyces griseus in submerged culture. Journal of Bacteriology 155, 357-366.

KOEPSEL, R. \& ENSIGN, J. C. (1984). Microcycle sporulation of Streptomyces viridochromogenes. Archives of Microbiology 140, 9-14.

Lechevalier, H. A. \& LechevalieR, M. P. (1980). The chemotaxonomy of actinomycetes. In Actinomycete Taxonomy, special publication 6, pp. 227-291. Edited by A. Dietz \& D. W. Thayer, Arlington, VA, USA: Society for Industrial Microbiology.

LoccI, R. (1989). Streptomyces and related genera. In Bergey's Manual of Systematic Bacteriology vol. 4, pp. 2451-2508. Edited by S. T. Williams, M. E. Sharpe \& J. G. Holt. Baltimore: Williams \& Wilkins.

MCBride, M. J. \& ENSIGN, J. C. (1987a). Effect of intracellular trehalose content on Streptomyces griseus spores. Journal of Bacteriology 169, 4995-5001.

MCBRide, M. J. \& ENSIGN, J. C. (1987b). Metabolism of endogenous trehalose by Streptomyces griseus spores and by spores or cells of other Actinomycetes. Journal of Bacteriology 169, 5002-5007.

Minnikin, D. E., Collins, M. D. \& Goodfellow, M. (1978). Fatty acids and polar lipid composition in the classification of Cellulomonas, Oeskova and related taxa. Journal of Applied Bacteriology 47, 87-95.

OCHI, K. (1987). Changes in nucleotid pools during sporulation of Streptomyces griseus in submerged culture. Journal of General Microbiology 133, 2787-2795.

Rho, Y. T., JeOng, B. C. \& LeE, K. J. (1988). Molecular cloning of alkaline protease in Streptomyces spp. and optimization of fer- 
mentation: role of alkaline protease in the cell differentiation. In Proceedings of the 3rd Conference on Molecular Biology \& Genetic Engineering vol. 3, pp. 57-62. Seoul, Korea: Korean Society of Molecular Biology.

Rho, Y. T., Kim, J. W. \& Lee, K. J. (1989). Regulation of alkaline protease biosynthesis in Streptomyces spp.: effects of culture environments on gene expression. In Proceedings of the 4th Conference on Molecular Biology \& Genetic Engineering vol. 4, pp. 91-94. Seoul, Korea: Korean Society of Molecular Biology.

Rho, Y. T., KIM, H. T., OH, K. H., Kang, H. I., Ward, A. C., Goodfellow, M., HaH, Y. C. \& LeE, K. J. (1992). Numerical identification of a Streptomyces strain producing spores in submerged culture. Korean Journal of Microbiology 30, 278-285.

Salas, J. A., Guijarro, J. A. \& Hardisson, C. (1983). High calcium content in Streptomyces spores and its release as an early event during spore germination. Journal of Bacteriology 155, 1316-1323.

Shin, H. S. \& LeE, K. J. (1986). Regulation of extracellular alkaline protease biosynthesis in a strain of Streptomyces sp. Korean Journal of Microbiology 24, 32-37.

Tung, B. S., Unger, E. R., Levin, B., Brasitus, T. A. \& Getz, G. S (1991). Use of unsaturated fatty acid auxotroph of Saccaharomyces cerevisiae to modify the lipid composition and function of mitochondrial membranes. Journal of Lipid Research 32, 1025-1038.

Wellington, E. M. H. \& Williams, S. T. (1978). Preservation of actinomycete inoculum in frozen glycerol. Microbios Letters 6, 151-157.

Williams, S. T., Goodfellow, M., Alderson, G., Wellington, E. M. H., Sneath, P. H. A. \& Sackin, M. (1983a). Numerical classification of Streptomycetes and related genera. Journal of General Microbiology 129, 1743-1813.

Williams, S. T., Goodfellow, M., Wellington, E. M. H., Vickers, J. C., Alderson, G., Sneath, P. H. A., Sackin, M. \& Mortimer, A. M. $(1983 b)$. A probability matrix for the identification of some streptomycetes. Journal of General Microbiology 129, 1815-1830. 